ROCZNIKI NAUK PRAWNYCH

Volume XXVIII, number $1-2018$

E n g $1 \mathrm{is} \mathrm{h} \quad \mathrm{v}$ e $\mathrm{rs}$ i o $\mathrm{n}$

DOI: http://dx.doi.org/10.18290/rnp.2018.28.1-2en

EWELINA KUMOR-JEZIERSKA

\title{
MATERNITY LEAVE OF A PRISON SERVICE OFFICER
}

\section{INTRODUCTION}

In the time of a demographic decline, the protection of parenthood is gaining importance. The statutory legislator strives to create solutions which will make it possible for parents to reconcile a career with parental duties. The Polish system of leaves related to birth and childcare took many years to develop. Substantial changes to the Labour Code have been introduced relatively recently by way of the Act of 24 July 2015 amending the Labour Code Act and certain other acts $^{1}$ and the Act of 28 May 2013 amending the Labour Code Act and certain other acts. ${ }^{2}$

The Polish Prison Service [henceforth referred to as PS] is a uniformed and armed apolitical formation subordinate to the Minister of Justice, having its own organisational structure. Its tasks are carried out mainly by prison officers. The civilians who are employed there under the regulations of labour law constitute auxiliary personnel to do tasks related to administrative, office or technical work. ${ }^{3}$ An officer working for the Prison Service enters into a public service relationship based on administrative law with the employing entity and is not an employee within the meaning of the Labour Code [henceforth abbreviated as LC]. ${ }^{4}$ The provisions of the common labour

Dr EwElina KumOR-JEZIERSKA is a research assistant at the Department of Labour Law and Social Policy, Faculty of Law and Administration of the Jagiellonian University; address: ul. Grodzka 53, 31-001 Kraków, Poland; e-mail: ewelina.kumor-jezierska@uj.edu.pl

${ }^{1}$ Journal of Laws of 2015, item 1220.

${ }^{2}$ Journal of Laws of 2013, item 675.

${ }^{3}$ M. КовAK, Służba Więzienna, in Stosunek służbowy w formacjach mundurowych, ed. W. Maciejko and P. Szustakiewicz. Legalis 2016/el, chap. 9; see Regulation of January 12, 2011 on defining positions in the Prison Service to be filled only by officers, Journal of Laws No. 20, item 106.

${ }^{4}$ Judgement of the Administrative Court of 28 October 2008, file ref. no. I OSK 1721/07, LEX no. 499777. 
law are implemented by way of an explicit reference contained in the Prison Service Act. Such reference is made in Article 165 of the Act of 9 April 2010 on the Prison Service 5 in respect of available parental rights. In line with this provision, a prison service officer has special rights related to parenthood specified in the Labour Code, with the exception of Article $186^{7}$ LC, unless the provisions of the PSA provide otherwise. It seems vital to analyse the maternity leave regulations in a situation where both parents or legal guardians are prison officers, or where one of them is a prison officer and the other is an employee or insured against sickness and maternity on a basis other than an employment relationship, e.g. a contract of mandate.

\section{MATERNITY LEAVE}

One of the most significant changes of late which entered into force on January 2, 2016, was the reduction of the range of leaves to maternity leave (basic) and parental leave. The institution of additional maternity leave was done away with, at the same time extending parental leave to 32 weeks when one child is born and to 34 weeks when two or more children are born at one birth. A female prison officer is entitled to maternity leave in connection with the birth of a child. Acquisition of the right to maternity leave is associated with the birth of a child occurring during the employment relationship and takes place regardless of seniority, the length of working time, the basis of the appointment, that is for the duration of preparatory service (which is 2 years in the PS) and permanently, that is for an indefinite period of time. Maternity leave is an entitlement which can be exercised only in kind and no equivalent may be granted in its place. We should also note that this leave implies an obligatory exemption from performing work related to childbirth, for a period of time regulated by statute. The current design of maternity leave serves two fundamental goals: to protect the health of the woman and her child, the intention being, among other things, to restore the woman's strength impaired by the pregnancy and childbirth, while the other goal is for the child to exercise its right to be looked after by at least one parent or other family member. ${ }^{6}$ The duration of this leave depends on the number of children born at one birth. Pursuant to Article $180 \S 1 \mathrm{LC}$ in connection

\footnotetext{
${ }^{5}$ Journal of Laws of 2017, item 631 [Prison Service Act, henceforth quoted as PSA].

${ }^{6}$ See A. SовсZYк, "Prawo dziecka do opieki rodziców jako uzasadnienie dla urlopu i zasiłku macierzyńskiego,” Praca i Zabezpieczenie Społeczne 9 (2015): 12.
} 
with Article 165 PSA, a prison officer is entitled to maternity leave in the amount of:

-20 weeks if one child is born at a single birth;

-31 weeks if two children are born at a single birth;

- 33 weeks if three children are born at a single birth;

- 35 weeks if four children are born at a single birth;

- 37 weeks if five or more children are born at a single birth.

When a maternity leave is granted, one week of leave corresponds to 7 calendar days (Article $183^{1} \S 1$ LC in connection with Article 165 PSA).

A female prison officer has the right to use part of her maternity leave, but no earlier than 6 weeks before the expected date of childbirth. In such a situation, after childbirth, she is entitled to the remainder of maternity leave until the entire period referred to in Article $180 \S 1 \mathrm{LC}$ has been used. The PSA does not contain any regulations concerning formal conditions to be met when individual leaves are applied for in connection with childbirth and upbringing. Nonetheless, such formal requirements are provided for by the Regulation of December 8, 2015 concerning applications related to the parental rights of employees and the documents accompanying them. ${ }^{7}$ This regulation was issued pursuant to Article $186^{8 \mathrm{a}}$ LC. Due to the general reference provided for in Article 165 PSA to the direct application of the provisions concerning individual parental rights specified in the Labour Code and the absence of specific regulations in this regard from the PSA, the formal requirements related to individual applications also apply to applications submitted by prison service officers.

In light of the above, the application of a prison officer to grant her a maternity leave before her due date should contain her full name as well as the date from which part of the maternity leave before childbirth is to be granted. In addition, the applicant is required to enclose a copy of a medical certificate issued in standard form, specifying the estimated date of delivery. ${ }^{8}$ This application is binding on the employer. If the prison officer did not take maternity leave before giving birth, the first day of the maternity leave is the day of childbirth. In this case, the maternity leave starts by operation of law and the eligible officer does not have to submit a formal application. ${ }^{9}$

\footnotetext{
${ }^{7}$ Journal of Laws, item 2243.

${ }^{8} \S 5$ of the Regulation of 8 December 2015 on applications concerning the parental rights of employees and the documents accompanying such applications.

${ }^{9}$ Within 21 days after the childbirth, a prison officer may submit a written application for granting her a parental leave in the full amount by virtue of Article $182^{1 \mathrm{a}} \S 1 \mathrm{LC}$ immediately after the maternity leave has expired (Article $179^{1} \S 1 \mathrm{LC}$ in connection with Article 165 PSA).
} 
The regulations of the Labour Code concerning maternity leave do not mention the possibility of taking up employment while the mother is using the leave. It is validly argued in the literature on labour law that employment during maternity leave runs counter to the purpose of maternity leave and is therefore inadmissible. ${ }^{10}$ Moreover, we should add that a prison officer may not undertake a gainful occupation outside the service without the superior's permission (Article $160 \S 1$ PSA).

\section{SURRENDER OF MATERNITY LEAVE}

A female prison officer is eligible for maternity leave while employed in prison service. Its use by the child's mother is a duty which she cannot waive. However, she is not obliged to use the whole of her maternity leave. The current regulations of the Labour Code provide for the possibility of sharing parental rights between the parents who have the status of an employee or an insured person on a basis other than an employment relationship. Pursuant to Article 165 PSA, both male and female officer have special rights related to parenthood specified in the Labour Code (except for Article $186^{7}$ LC and a situation when the provisions of the Prison Service Act provide otherwise). Therefore, not only an employee who is a father raising a child but also a prison officer who is a father raising a child is eligible for the remainder of the maternity leave unused by the child's mother who has the status of a prison officer. ${ }^{11}$ As a result, on the basis of the Labour Code and the Prison Service Act, after taking at least 14 weeks of maternity leave following the delivery, a female prison officer may surrender the remaining part of the leave and return to service, if:

- the remainder of the maternity leave will be taken by a male employee who is the father raising the child, or

- for a period corresponding to the remainder of the maternity leave, personal custody of the child will be provided by the insured person, that is

\footnotetext{
${ }^{10}$ P. SEKULSKI, "Dopuszczalność zatrudnienia w okresie wykorzystania urlopów związanych $\mathrm{z}$ rodzicielstwem," in Uprawnienia pracowników zwiąane z rodzicielstwem $w$ świetle przepisów prawa pracy i ubezpieczeń społecznych, ed. J. Czerniak-Swędzioł, (Warszawa: Wydawnictwo Wolters Kluwer Polska, 2016), 140.

${ }^{11}$ The situation is different, for instance, in the case of police officers because Article 79 para. 1 of the Act on the Police (Journal of Laws of 2017, item 2067) explicitly states that a police officer is entitled to employee rights related to parenthood specified in the Labour Code, unless the provisions of this act provide otherwise. If both parents or guardians are officers, only one of them may exercise their rights in this regard.
} 
the father of the child who, in order to provide such custody, has interrupted his gainful activity, or

- the remainder of the maternity leave will be taken by a father raising the child who remains in a public service relationship with the prison service.

The father's employment at the time of the delivery is irrelevant, but it is relevant when he is taking over the care of the child. ${ }^{12}$ It should be noted that only the father of the child who raises the child is entitled, in other words one who actually has the custody of the child and is a father in the light of provisions of the Family and Guardianship Code (henceforth abbreviated as FGC. ${ }^{13}$ The upbringing of a child entails a concern for the child's physical and spiritual development and preparing it for work for the benefit of society, according to her abilities and talents. ${ }^{14}$

A female prison officer who wants to exercise this right is obliged to submit a written application concerning her waiver of the remaining part of the maternity leave within a period not shorter than 7 days before resuming service (Article $180 \S 8$ LC in connection with Article 165 PSA). The application should include her full name and specify the date of her return to service. Depending on whether the father raising the child who "takes over" the rest of the maternity leave has the status of an employee, a prison officer or a person insured on a basis other than employment, the applicant attaches relevant documents to the application. In the first case, she is to attach a copy of the application for the remaining portion of the maternity leave submitted by an employee or an officer-the father raising the child. In the other case, the application must be accompanied by a copy of the declaration made by the insured father of the child that he has stopped his gainful activity in order to take care of the child for a period corresponding to the remainder of the maternity leave. The official employer is obliged to accept an application of a female prison officer submitted in a timely fashion renouncing her right to the maternity leave in favour of the eligible father of the child. A refusal would only be justified if the child's mother did not use the compulsory part of the leave. It should be noted that the early return of the female officer from maternity leave to service may cause difficulties in terms of work

\footnotetext{
${ }^{12}$ See A. SoвсZYк, Kodeks pracy. Komentarz. Legalis 2017/el., commentary for Article 180, argument no. 8.

${ }^{13}$ The father of the child is a man to whom a presumption of paternity applies (Article 62 FGC) or whose paternity has been established by way of recognition or by virtue of a court decision (Article 72 para. 1 FGC).

${ }^{14}$ See B. BuRY, "Prawo ojca dziecka niebędącego pracownikiem do realizacji uprawnień rodzicielskich związanych z urlopem macierzyńskim,” Monitor Prawa Pracy 5 (2016): 246.
} 
organisation. During maternity leave, the position occupied by the employee on leave may be filled by another employee, as pursuant to Article 60b PSA, the head of the organisational unit may employ a person on the basis of a fixed-term employment contract covering the period of such absence.

\section{AN OFFICER HOLDING A CERTIFICATE OF HER INCAPACITY FOR INDEPENDENT EXISTENCE}

The Labour Code legislator has also provided for special situations where a child's mother has the right to waive her entitlement to part of her maternity leave. Pursuant to Article $180 \S 6$ LC in relation to Article 165 PSA, a female prison officer who holds a certificate of incapacity for independent existence, and having used at least 8 weeks of maternity leave after giving birth, is entitled to surrender the remaining part of the maternity leave as long as it is used by another eligible person. It should be pointed out that the latest amendment of July 24, 2015 has significantly broadened the range of people who can take over the care of a child. A woman with the status of a prison officer, based on the Labour Code and the Prison Service Act, may share the custody of a child both with a father raising it who is in an employment relationship, as well as with a father raising a child who is a prison officer, that is one who is in an established public service relationship. In addition, the unused portion of maternity leave may be "taken over" by another immediate family member who has the status of an employee or officer of prison service. For a period corresponding to the period left until the end of maternity leave, personal custody of the child may also be exercised by an insured person - the child's father or another insured member of the immediate family, who has interrupted a gainful activity in order to provide such care. The legislator does not provide for a conflict-of-law rule indicating which of the entitled persons has priority in the acquisition of rights - the father or a member of the immediate family. Naturally, it should be assumed that an immediate family member should be granted such a right only if the father raising the child renounces it. ${ }^{15}$ In connection with the extension of the circle of persons eligible for benefits related to parenthood, new definitions of the insured mother of the child, the insured father, an employee who is a member of the immediate family, and an insured person who is another member of the

\footnotetext{
${ }^{15}$ See E. MANIEwSKA and K. JAŚKOWSKI, Komentarz aktualizowany do Kodeksu pracy, LEX 2017/el., commentary for Article 180, argument no. 11; BURY, "Prawo ojca dziecka," 247.
} 
immediate family were introduced in Article $175^{1}$ of the Labour Code. The legislator does not specify the persons who count as members of the closest family entitled to exercise parental rights, but refers to Article 29 para. 5 of the Act of 25 June 1999 on cash benefits from social insurance in the event of sickness and maternity. ${ }^{16}$ However, this provision does not mention the circle of persons regarded as members of the immediate family. It is correctly asserted in the literature of labour law that Article $175^{1}$ point $4 \mathrm{LC}$, in the part which does not enumerate the eligible persons, is inconsistent with the constitutional principle of the rule of law. ${ }^{17}$ The provision does not make it clear whether the entitled person is a member of the closest family on the mother or father's side or perhaps on the child's side. It can be assumed that the closest family member should be interpreted as a person who has consanguinity, affinity with or is married to the child's parent. However, it seems that the degree of relationship should not be the sole criterion for including a particular person in the closest circle of family members. ${ }^{18}$

A prison officer is not obliged to surrender part of her maternity leave. This is a right that she can but does not have to exercise. If, however, she decides to surrender part of her maternity leave and declares her willingness to resume work, she is obliged to submit a written application and attach a copy of a legally binding decision on her inability to exist independently and indicate the date of her return to service. Moreover, if the remaining part of the maternity leave is to be taken by an employee or a prison officer (the father raising the child), his application is accompanied by a copy of the application. If the remainder of the maternity leave is taken by an employee or a prison officer, that is another member of the closest family, the application must be accompanied by a copy of the application for granting the remaining part of the employee's or officer's maternity leave. On the other hand, if the personal custody of the child is to be provided by the insured person, that is the father of the child, or another member of the closest family, in the first instance the application is accompanied by a copy of the statement of the insured person (the father of the child), and in the second case by a statement of the insured person (another member of the closest

\footnotetext{
${ }^{16}$ Journal of Laws of 2017, item 1368.

${ }^{17}$ K. KULIG, "Członek najbliższej rodziny jako osoba nabywająca uprawnienia związane z rodzicielstwem,” Monitor Prawa Pracy 3 (2016): 135.

${ }^{18}$ For a broader view, see E. KUMOR-JEZIERSKA, "Komentarz do rozporządzenia z dnia 8 grudnia 2015 r. w sprawie wniosków dotyczących uprawnień pracowników związanych z rodzicielstwem oraz dokumentów dołączanych do takich wniosków," in Akty wykonawcze prawa pracy. Komentarz, ed. K.W. Baran (Warszawa: Wydawnictwo Wolters Kluwer Polska, 2016), 204-5.
} 
family) about the interruption of gainful occupation in order to take care of the child for a period corresponding to the period remaining until the end of maternity leave. The said application concerning the surrender of part of the maternity leave is to be submitted by the eligible mother not later than 7 days before her expected resumption of service. The question arises as to whether a person whose inability to live independently has been determined will be able to continue service in his or her previous post after surrendering maternity leave. First of all, it should be clarified when incapacity for independent existence is declared. This concept is not defined in the Act of 18 February 1994 on pension provision for officers of the Police, Internal Security Agency, Foreign Intelligence Agency, Military Counterintelligence Service, Central Anti-Corruption Bureau, Border Guard, Government Protection Bureau, State Fire Service and Prison Service and their families. ${ }^{19}$ However, it is provided for by the Act of 17 December 1998 on old-age pensions and disability pensions from the Social Insurance Fund. ${ }^{20}$ In line with Article 13 para. 5, incapacity for independent existence is declared when a person's bodily functions are compromised to an extent that necessitates permanent or long-term care and assistance of another to satisfy the basic life needs of the former. Jurisprudence indicates that a person who is unable to live independently is both one who-due to impaired bodily function-requires permanent or long-term care provided by another, and a person who-due to impaired bodily function-requires permanent or long-term assistance from another person. Therefore, in relation to the term "incapacity for independent existence," a distinction should be made between care, which denotes nursing (i.e. assurance of mobility, nutrition, satisfying physiological needs, maintaining personal hygiene, etc.) and assistance in dealing with the basic things in everyday life, such as shopping, making payments, or visiting a doctor. When combined, all of the above factors fully reflect the scope of the term "incapacity for independent existence." 21

\footnotetext{
${ }^{19}$ Journal of Laws of 2016, item 708.

${ }^{20}$ Journal of Laws of 2017, item 1383.

${ }^{21}$ See the judgement of the Regional Court of Warszawa-Praga of 23 January 2017, file ref. no. VII U 598/16, LEX no. 2206792; the judgement of the Court of Appeal in Gdańsk of March of March 19, 2013, file ref. no. III AUa 1577/12, LEX no. 1298892; the judgement of the Court of Appeal in Rzeszów of 6 March 2013, file ref. no. III AUa 1235/12, LEX no. 1292818. The literature indicates that - from a formal point of view - nothing prevents a person capable of or only partially incapable of working from being declared as incapable of living independently, but this person will not acquire the right to a nursing allowance. For this reason, in practice, inability to live independently - even though the term constitutes a separate category of jurisprudence-is never declared in isolation from total incapacity for work because it would be pointless as these
} 
It should be pointed out that one of the basic requirements necessary to be an officer of the Polish prison Service is the physical and mental capacity of the person (Article 38 para. 8 of the Prison Service Act). In the case of PS officers, their inability to work and inability to live independently, pursuant to the rules set forth in the Act on pensions from the Social Insurance Fund (Fundusz Ubezpieczeń Spotecznych, FUS), is determined by medical commissions subordinate to the minister competent for internal affairs. ${ }^{22}$ Therefore, in the situation at hand, despite her willingness to return to service in the position she has held so far, the prison officer will not be able to perform her duties due to her health condition. The employer is not to admit a PS officer to perform his or her service without a valid opinion stating that there are no contraindications to work in a specific position. However, the possession of a opinion of incapacity for independent existence and the surrender of the remainder of the maternity leave by the mother of the child are prerequisite to enable another entitled person to use the remaining portion of the maternity leave.

\section{ABANDONMENT OF A CHILD}

The Polish Labour Code regulates the situation when the mother of a child, who is employed, abandons the child during maternity leave. Under such circumstances, the father raising the child who is an employee, or another employee who is a member of the closest family has the right to use the remaining part of the maternity leave. Thus, if a female prison service officer abandons her child while on maternity leave, the father raising the child who is an employee or a PS officer, or another family member who is an employee or a PS officer is entitled to the part of the maternity leave remaining after the day when the child was abandoned. However, the entitled person may not take maternity leave earlier than after the mother has taken at least eight weeks' maternity leave after giving birth. Moreover, the total duration of maternity leave and maternity leave plus the period of receiving maternity allowance for the period corresponding to the period of

two concepts are normatively connected; see J. CEGLARSKA-JóźwIAK, "Niezdolność do samodzielnej egzystencji," Praca i Zabezpieczenie Spoteczne 11 (2011): 16.

${ }^{22}$ Article 21 para. 2 of the Act of February 18, 1994 on pension provision for officers of the Police, Internal Security Agency, Foreign Intelligence Agency, Military Counterintelligence Service, Central Anti-Corruption Bureau, Border Guard, Government Protection Bureau, State Fire Service and Prison Service and their families. 
such a leave may not exceed the duration of maternity leave referred to in Article $180 \S 1$ LC. The legislator does not define the notion of child abandonment in the provisions of labour law. However, the term "abandons" appears as a causative act of an offence under Article 210 of the Penal Code. In the literature of criminal law, abandonment is typically interpreted as a form of desertion, that is leaving the child on her own and moving away from it, even if it turns out that the child has not been exposed to any danger, for example has been quickly found and a third party assisted her. ${ }^{23}$ Therefore, child abandonment is accompanied by the intention of leaving the child on her own without the care of others. However, proving the mother's intention to behave in a certain way is difficult, in many specific situations, the time when the child is left without care may help to decide whether or not abandonment has taken place.

A general obligation to comply with the provisions of the law has been imposed on prison service officers, as they are obliged to act in accordance with their professional oath and to uphold the law, in particular the Prison Service Act and regulations issued on its basis (Article 157 para. 1 PSA). The public service relationship established by way of appointment contains many features that distinguish it from other employment relationships. A number of special requirements are essential (for example, Polish citizenship, the exercise of full public rights, physical and mental capacity to perform service). The recruitment process is unique, PS officers have a broader range of duties than in the case of a contractual employment relationship, which also applies to conduct outside the workplace; there is a strengthened system of responsibility, including disciplinary responsibility, availability and the right of the relevant superior to make unilateral changes to the nomination relationship. ${ }^{24}$ In addition, PS officers and regular employees should demonstrate adequate general and professional background as well as high morals, learn systematically and improve their professional qualifica-

\footnotetext{
${ }^{23}$ R.A. STEFAŃSKI, "Przestępstwo porzucenia,” Prokuratura i Prawo 5 (1997): 47-48; A. RATAJCZAK, Przestępstwa przeciwko rodzinie, opiece i młodzieży w systemie polskiego prawa karnego (zagadnienia wybrane) (Warszawa: Wydawnictwo Prawnicze, 1980), 212-13; see also S. HYPŚ, "Komentarz do art. 210," in Kodeks karny. Komentarz, ed. A. GrzeŚKowiaK and K. WiAK (Warszawa: Wydawnictwo C.H. Beck, 2014), 833; A. KiLIŃSKA-PĘKACZ, "Przestępstwo porzucenia dziecka," Prokuratura i Prawo 4 (2016): 22-34.

${ }^{24}$ See E. KUMOR-JEZIERSKA, "Dokumentacja w stosunkach zatrudnienia nawiązanych na podstawie ustawy o służbie więziennej," in Dokumenty $w$ zatrudnieniu na podstawie pragmatyk stużbowych. Wzory i komentarze, ed. K.W. BARAN and M. Wujczyk (Warszawa: Wydawnictwo Wolters Kluwer Polska, 2015), 544.
} 
tions. ${ }^{25}$ Thus, the abandonment of a child by a PS officer certainly undermines the service she performs. On the other hand, under labour law, such behaviour is a prerequisite for the father of the child or another entitled family member to benefit from the unused portion of the maternity leave. It should also be pointed out that "abandonment," as provided for in the Labour Code, is not a concept identical to "abandonment" under criminal law and it is also not necessary for the mother to be sentenced or at least charged under Article 210 of the Penal Code. It seems that "abandonment" under the Labour Code is a broader notion and also encompasses behaviours which do not meet the criteria of a prohibited act under Article 210 of the Penal Code. ${ }^{26}$

\section{HOSPITALISATION OF A PRISON SERVICE OFFICER}

Pursuant to Article $180 \S 10$ in relation to Article 165 of the Prison Service Act, a female prison officer who is staying in a hospital or another medical facility providing both in-patient and 24-hour health care services due to her health condition which prevents her from delivering personal childcare, having taken at least 8 weeks of maternity leave after giving birth, may interrupt her maternity leave for the duration of her stay in that hospital or medical institution. The above entitlement is subject to the following conditions:

- part of the maternity leave for this period must be taken by an employee or a PS officer (the father raising the child) or an employee or a PS officer (another member of the immediate family) or

- personal custody of the child during this time will be exercised by an insured person - the father of the child or another member of the closest family who, in order to provide this custody, interrupted his or her gainful activity.

It should be clarified that in-patient and 24-hour health care services other than hospital care stands for care, nursing, palliative and hospice services, long-term care, therapeutic rehabilitation, treatment of addictions, psychiatric health care and spa treatment provided to patients whose state of health requires the provision of 24-hour or all-day health services in suitably

\footnotetext{
${ }^{25}$ http://www.sw.gov.pl/strona/Charakterystyka-sluzby-pracy-w-Sluzbie-Wieziennej, accessed August 9, 2017.

${ }^{26}$ KuLIG, “Członek najbliższej rodziny,” 137.
} 
a equipped and permanent space. ${ }^{27} \mathrm{~A}$ prison service officer should resume the maternity leave upon ending her stay in the above-mentioned medical facility. In turn, an eligible person who used maternity leave during that time is to interrupt the maternity leave.

\section{DEATH OF AN OFFICER}

If a prison officer dies while on maternity leave, an employee or a prison officer who is the father raising the child or an employee or another PS officer-another member of the closest family, is entitled to the portion of the maternity leave remaining after the day of the officer's death (Article $180 \S$ 12 Labour Code in connection with Article 165 of the Prison Service Act). The total duration of maternity leave and maternity leave plus the period of maternity allowance for the period corresponding to the period of such a leave may not exceed the duration of a full maternity leave according to the number of children born at one birth. In this case, part of the maternity leave is granted at the written request of an employee or a PS officer-the father raising the child or an employee or a PS officer-another member of the closest family (Article $180 \S 16$ LC in relation to Article 165 PSA). The provisions of the Labour Code do not fully specify whether the entitled person at any time acquires the right to the remainder of the maternity leave which was not used by the mother of the child, or only until the expiry of the maximum length of maternity leave counting from the day of childbirth. It seems that the entitled person may use part of the maternity leave after the day of the mother's death, but not longer than until the expiry of the maximum length of maternity leave (depending on the number of children born at one birth) calculated from the day of childbirth (if the mother of the child did not take part of the maternity leave before childbirth) ${ }^{28}$

\section{EARLY TERMINATION OF MATERNITY LEAVE}

In the Labour Code, the legislator also specifies situations when the portion of maternity leave following childbirth is shortened. This happens in the following cases:

\footnotetext{
${ }^{27}$ Article 2 para. 1 point 12 of the Act of 15 April 2011 on medical activity, Journal of Laws of 2016, item 1638 .

${ }^{28}$ KUMOR-JEZIERSKA, “Komentarz do rozporządzenia,” 247.
} 
- stillbirth or death of a child within 8 weeks of her life; the PS officer is entitled to 8 weeks' holiday following the birth but not less than 7 days from her child's death. An officer who has given birth to more than one child at one birth is entitled to maternity leave in the amount dependent on the number of children remaining alive;

- death of a child after 8 weeks of life; the PS officer retains the right to maternity leave for a period of 7 days from the date of her child's death. A PS officer who has given birth to more than one child at one birth is entitled to maternity leave in the amount depending on the number of children remaining alive, but no less than for 7 days from the day of the child's death (Article $180^{1}$ LC in relation to Article 165 PSA);

- abandonment of a child by a PS officer or placement of a child on the basis of a court ruling in foster custody, in a care and treatment facility, in a nursing and care facility, or in a medical rehabilitation facility; the officer is not entitled to the portion of maternity leave starting after the day of abandonment or placement of the child in foster custody, in a care and treatment facility, in a nursing and care facility or in a medical rehabilitation facility. However, maternity leave after childbirth may not be less than 8 weeks (Article 182 LC in connection with Article 165 of the Prison Service Act).

\section{INTERRUPTION OF MATERNITY LEAVE}

The rule is that a prison service officer, that is the mother of a child, is to use maternity leave uninterruptedly. By virtue of Article 181 LC in connection with Article 165 PSA, the legislator provided for an exception to this rule. Maternity leave may be interrupted if two conditions are met: the child is hospitalised and the eligible mother has used at least 8 weeks of her maternity leave since the childbirth. A PS officer is not obliged to interrupt her maternity leave, as it is only her entitlement, which she is free to use or not. If she elects to exercise this right, the official employer is obliged to enable her to resume service during the break in the course of maternity leave and to grant her maternity leave again within the period indicated by her in connection with the end of the child's stay in hospital. Therefore, the length of interruptions in maternity leave depends on the length of hospitalisation of the child. 


\section{PROTECTION OF THE PUBLIC SERVICE RELATIONSHIP}

During maternity leave, the permanence of the public service relationship involving a prison service officer is under protection, but not by virtue of Article 177 , paragraph 1 of the Code of Criminal Procedure, but pursuant to Article $108 \S 1$ LC but Article 108 PSA. Therefore, in such a case, the provisions of the Act on Prison Service preclude the application of the Labour Code provisions.

It should be noted that the protection of permanence of the employment relationship provided for in Article 177 LC applies only to persons bound by an employment relationship and concerns the female employee, that is the child's mother during her pregnancy and while on maternity leave, and the male employee, that is the father raising the child while using the maternity leave. ${ }^{29}$ Therefore, as regards persons entitled to leaves related to the birth and upbringing of a child who are in an employment relationship, the protection does not cover employees who are regarded as the closest family and have "taken over" part of the maternity leave in situations specified in the Labour Code. The personal scope of protection associated with parenthood under PSA is wider as it covers women who have the status of a PS officer while pregnant and on maternity leave, leaves on the terms of parental leave, and parental leave, and men - fathers raising a child with the status of an PS officer while they benefit from the unused part of maternity leave, leave on the terms of maternity leave, paternity leave, parental leave, and prison service officers (irrespective of their gender) who are regarded as the immediate family and take maternity leave, leave on the terms of maternity leave or parental leave-in the cases indicated in Article $180 \S 6-16$, Article $182^{1 \mathrm{~g}}$, Article $183 \S 2$ of the Labour Code.

In the provision of Article 108 of the Prison Service Act, the legislator also enumerates cases when the special protection of the permanence of public service relationship is revoked during pregnancy or the use of the abovementioned types of leave. The first is the situation when a prison officer submits a written withdrawal from service (Article 96 para. 1 point 2 PSA), and the second is the case when an officer is appointed to a different state service (Article 96 para. 2 point 2 PSA). The other cases are: liquidation of

\footnotetext{
${ }^{29}$ Protection of the permanence of the employment relationship between a female employee who is a mother also occurs during parental leave (Article $182^{1 \mathrm{~g}} \mathrm{LC}$ ) and leave on the terms of maternity leave (Article $183 \S 2$ LC). In the case of an employee who is a father raising a child, protection of the employment relationship also takes place during parental leave (Article $182^{1 \mathrm{~g}} \mathrm{LC}$ ), leave on the terms of maternity leave (Article $183 \S 2$ LC), and paternity leave (Article $183^{2} \S 3$ LC).
} 
an organisational unit or its reorganisation combined with a reduction in the staffing if the transfer of a prison officer to another organisational unit or to a lower service position is not possible (Article 96 para. 2 point 4 PSA); a final court ruling awarding a disciplinary measure resulting in expulsion from service; conviction by final judgement to imprisonment if the enforcement of this punishment has not been suspended conditionally; intentional offence prosecuted by public indictment or an intentional fiscal offence prosecuted by public indictment or an intentional fiscal offence; a final court ruling imposing a penal measure of deprivation of public rights or a penal measure prohibiting the service as a prison officer; absence from service for a period exceeding 3 months due to temporary arrest; renunciation of Polish citizenship; abandonment of service by an officer; death of an officer; confirmation of the disappearance of an officer (Article 97 para. 1 points 210 PSA).

\section{LEAVE ON THE TERMS OF MATERNITY LEAVE}

A prison service officer who is not a biological mother of a child but has accepted the child to raise her and applied to a guardianship court for institution of proceedings concerning the adoption of the child or who has accepted a child for upbringing as a foster family (except for a professional foster family) up to the age of 7 , while in the case of a child whose compulsory schooling has been deferred, no longer than up to the age of 10 years, has the right to leave on the terms of maternity leave. It should be noted that a PS officer is eligible for leave on the terms of maternity leave regardless of gender because the Labour Code grants this right to an employee, and the reference contained in Article 165 of the Prison Service Act also applies prison service officers at large. The legislator does not therefore give priority to adoptive mothers or foster mothers, granting fathers, both adoptive and foster ones, equal rights to take leave on the terms of maternity leave. ${ }^{30}$ The duration of maternity leave depends on the number and age of children in adoption or foster care, being:

-20 weeks if one child is accepted,

- 31 weeks if two children are accepted simultaneously,

- 33 weeks if three children are accepted simultaneously,

\footnotetext{
${ }^{30}$ See W. WŁodarczyK, Kodeks pracy. Komentarz, ed. K.W. Baran. LEX 2016/el., commentary for Article 183, argument no. 3.
} 
- 35 weeks if four children are accepted simultaneously,

- 37 weeks if five children or more are accepted simultaneously,

but no longer than until the child reaches the age of 7 , and in the case of a child whose compulsory schooling has been deferred no longer than until the child reaches the age of 10 . On the other hand, if an employee has accepted a child up to the age of 7 , and in the case of a child whose compulsory schooling has been deferred until the age of 10, the employee is entitled to 9 weeks of leave on the terms of maternity leave. This is a situation where the child is almost 7 or 10 years old at the time of acceptance (and therefore it will not be possible to take full leave until the child reaches the age of 7 or 10), the legislator guarantees the employee 9 weeks' maternity leave, even if the child turns 7 (or 10) during the leave.

Leave on the terms of maternity leave is granted at the written request of a prison service officer. ${ }^{31}$ It is an optional leave so the eligible officer does not have to take it. ${ }^{32}$ The provisions of labour law do not specify the time limit within which the entitled person should apply for leave on the terms of maternity leave. This implies that the employer will be obliged to grant this leave even from one day to the next, if such a date is provided in the application. The application for leave on the terms of maternity leave should include:

- the officer's full name,

- the child's (children's) full name and date of birth accepted for upbringing or accepted for upbringing in a foster family, who is the basis the granting of the leave on the terms of maternity leave,

- an indication of the period for which leave on the terms of maternity leave is to be granted.

The application is accompanied by: the officer's statement on the date of accepting a child (children) for upbringing and a copy of an application for the institution of adoption proceedings, containing the date of birth of the child (children) with a certificate of the guardianship court of the date when

\footnotetext{
${ }^{31}$ The amendment of 24 July 2015 amending the Labour Code Act and certain other acts abolished the institution of additional leave on the terms of maternity leave, while extending the period of parental leave.

${ }^{32}$ For a different interpretation, see M. ZiELENIECKI, Prawo pracy, ed. J. STALina (Warszawa: Wydawnictwo C.H. Beck, 2016), 486. The author argues that the feature of maternity leave on the terms of maternity leave is its obligatory character implying that the leave should start on the day when a child is accepted for upbringing and an application is submitted to the guardianship court for adoption thereof and for granting the full measure of maternity leave which the employee is entitled to.
} 
the application was lodged or a certificate of the guardianship court of the date when the application was lodged for the adoption of a child (children), containing the date of birth of the child (children) or a copy of a final decision of the guardianship court to place the child (children) in a foster family, or a copy of a civil-law agreement concluded between the foster family and a starost; a copy of the final decision to postpone compulsory education if the application concerns a child in respect of whom such a decision has been taken (Article $183 \S 6 \mathrm{LC}$, Article $186^{8 \mathrm{a}} \mathrm{LC} \S 22$ of the regulation in relation to Article 165 PSA).

Adoptive/foster parents cannot take leave on the terms of maternity leave simultaneously because the provisions regulating the possibility of dividing the maternity leave specified in Article 180 § 4-17 LC in relation to Article 165 PSA. Since the legislator adopted the use of references, it is difficult to interpret the regulations in question correctly. In the case of biological parents, the division of entitlements is determined by the childbirth and puerperium of the mother, who is obliged to use a predetermined portion of the maternity leave mainly for regeneration. On the other hand, if a child is accepted for upbringing, the main purpose of the leave is to take care of the child. Every adoptive/foster parent, regardless of their gender, is entitled to leave on the terms of maternity leave. Therefore, in the case of leave on the terms of maternity leave, unlike maternity leave, there is no statutory obligation to use its first 14 weeks by a prison service officer-the adoptive/foster mother of the child. Adoptive/foster parents who have the status of an employee or a prison service officer can share the leave on the terms of maternity leave in any configuration. Thus, the use of this leave may be stated by an employee or a prison officer (adoptive/foster father) who, having taken at least 14 weeks' leave on the terms of maternity conditions, may surrender it and return to work/service, while the remaining part of the leave on the terms of maternity leave will be taken by a female employee or a female PS officer-the adoptive/foster mother raising a child or for a period corresponding to the period remaining until the end of the maternity leave, personal custody of the child will be provided by the insured person-adoptive/foster mother, who will have to interrupt her gainful activity in order to take care of the child.

A prison service officer (i.e. a woman or a man) taking leave on the terms of maternity leave, who holds a certificate of incapacity for independent existence, may surrender the remainder of the leave earlier than after taking at least 8 weeks of leave, as the priority should be to provide care for the child by at least one parent or another closest member of the family. In such 
a case, the remaining unused part of the leave on the terms of maternity leave should be taken by an employee or a prison officer-the other adoptive/foster parent raising a child (regardless of their gender), or by an employee or a prison officer-another member of the closest family, or for a period corresponding to the period remaining until the end of the maternity leave; personal custody of the child will be exercised by the other adoptive parent of the child who is insured (regardless of the gender) or by another member of the closest family covered by insurance, who has interrupted the gainful activity in order to provide such custody. ${ }^{33}$

Moreover, a PS officer (i.e. a man or a woman) taking leave on the terms of maternity leave, who stays in a hospital or other medical facility providing therapeutic services such as in-patient and 24-hour health care services, may interrupt the leave on the terms of maternity leave for the duration of the stay in that hospital or such facility due to his or her state of health preventing them from taking personal care of the child. Therefore, the person who is entitled to take the remaining part of leave on the terms of maternity leave is an employee or prison officer (the other adoptive/foster parent) bringing up a child or another member of the immediate family; or the personal custody of the child during this period will be exercised by the other adoptive/foster parent who is insured or another member of the immediate family who is insured, who will interrupt his or her gainful activity in order to provide such care.

In the case of abandonment of a child by a PS officer-the adoptive or foster parent during the leave on the terms of maternity leave, to an employee or an SW officer-the other adoptive/foster parent who is an employee or a PS officer (regardless of the gender) raising the child or an employee or a PS officer-another member of the closest family is eligible for the part of the leave on the terms of maternity leave from the day following the day of the abandonment.

On the other hand, in the event of a PS officer's death occurring during his or her leave on the terms of maternity leave, the part of the leave starting after the day when the death occurred can be used by an employee or a PS officer - the other adoptive/foster parent (regardless of the gender) raising the child or an employee or a PS officer who is a member of the immediate family member.

\footnotetext{
${ }^{33}$ See KumOR-JEZIERSKA, "Komentarz do rozporządzenia,” 233-34.
} 


\section{REMUNERATION DURING MATERNITY LEAVE}

The monthly remuneration of a prison service officer for the period defined by the provisions of the Labour Code as the period of maternity leave or leave on the terms of maternity leave is $100 \%$ of the monthly salary. A PS officer receives a base remuneration plus allowances on a permanent basis and other monetary receivables due for the last service position held, considering the changes that occurred during this period affecting the right to remuneration and other pecuniary receivables or their amount. The abandonment of the notion of salary underscores the difference between public service and an employment relationship, although in essence it has a similar function just like remuneration. ${ }^{34}$ The monthly remuneration of a female prison officer who submits an application no later than 21 days after the birth to apply for a full-time parental leave directly after the maternity leave amounts to $80 \%$ of the monthly remuneration for the entire period corresponding to the period of such leave. An analogous percentage base is applied for a male prison officer who submits an application no later than 21 days after accepting a child for upbringing and applies to the guardianship court for instituting proceedings concerning adoption of the child or after accepting her for upbringing as a foster family-except for a professional foster family, and who will apply directly after a leave on the terms of maternity leave for full-time parental leave. In the situation when the amount of an officer's remuneration less an advance income tax payment related to natural persons is lower than the amount of the parental benefit determined in the Act of November 28, 2003 on family benefits, ${ }^{35}$ the amount of an officer's remuneration less an advance income tax payment related to natural persons is increased to the amount of the parental benefit (Article 60a para. 1 and paras. 3-4 of the Prison Service Act).

\section{SUMMARY}

Maternity leave is the first longer, compulsory paid leave related to the birth and upbringing of a child. It is possible for the child's mother with a PS status to surrender party of maternity leave only if the care of the child is continued by another eligible person. Due to the fact that the act on prison

\footnotetext{
${ }^{34}$ Kовак, Stużba Więzienna, chap. 9.

${ }^{35}$ Journal of Laws of 2016, items 1518 and 1579, and of 2017, item 60.
} 
service refers directly to the application of the Labour Code provisions with regard to parental rights, prison service officers in Poland (women and men) may exercise parental rights on the same terms as employees under the Labour Code (with the exception of Article $186^{7} \mathrm{LC}$ and in situations when the provisions of the PSA provide otherwise). Dynamic changes in childbirth and childcare leaves have not satisfactorily simplified and harmonised the relevant provisions. The legislator still makes use of a large number of references to other regulations, and some provisions of the Labour Code contain a large number of units, for example Article 180 LC. The numbering of some LC provisions is complicated, sometimes its regulations are even illogical, which certainly makes their interpretation difficult for employers, as well as for those interested in taking these leaves. However, the legislator strives to extend parental rights and make them more flexible, and this direction of changes should be evaluated positively. One of the key changes introduced by the recent amendment of the Labour Code and the Prison Service Act is to enable parents to share parental rights if they have the status of an employee or a prison service officer or if one of them has a social insurance cover for sickness and maternity under another title, e.g. a contract of mandate. Furthermore, in certain specific situations, the circle of persons entitled to "take over" part of maternity leave by another member of the closest family has been extended. However, the lack of a specific indication in Article $175^{1}$ LC who can be included in this group raises serious doubts and is inconsistent with the constitutional principle of the rule of law. Moreover, if several entitled persons are willing to take part of their maternity leave in situations specified in the Labour Code, the question of determining the priority order of eligible persons is also problematic. It should be noted that the proper definition of entitled persons is crucial, as it entails the payment of benefits paid from public funds, and additionally - under the Prison Service Act - PS officers (regardless of their gender and family relationship of the eligible persons) who take maternity leave have their public service relationship protected pursuant to Article 108.

\section{BIBLIOGRAPHY}

NORMATIVE ACTS

Ustawa z dnia 18 lutego 1994 r. o zaopatrzeniu emerytalnym funkcjonariuszy Policji, Agencji Bezpieczeństwa Wewnętrznego, Agencji Wywiadu, Służby Kontrwywiadu Wojskowego, Służby Wywiadu Wojskowego, Centralnego Biura Antykorupcyjnego, Straży Granicznej, Biura Ochrony Rządu, Państwowej Straży Pożarnej i Służby Więziennej oraz ich rodzin [Act 
of 18 February 1994 on pension provision for officers of the Police, Internal Security Agency, Foreign Intelligence Agency, Military Counterintelligence Service, Central Anti-Corruption Bureau, Border Guard, Government Protection Bureau, State Fire Service and Prison Service and their families], Journal of Laws of 2016, item 708.

Ustawa z dnia 17 grudnia 1998 r. o emeryturach i rentach z Funduszu Ubezpieczeń Społecznych [Act of 17 December 1998 on old-age pensions and disability pensions from the Social Insurance Fund], Journal of Laws of 2017, item 1383.

Ustawa z dnia 25 czerwca 1999 r. o świadczeniach pieniężnych z ubezpieczenia społecznego w razie choroby i macierzyństwa [Act of 25 June 1999 on social insurance cash benefits in the event of sickness and maternity], Journal of Laws of 2017, item 1368.

Ustawa z dnia 9 kwietnia 2010 r. o Służbie Więziennej [Act of 9 April 2010 on Prison Service], Journal of Laws of 2017, item 631.

Ustawa z dnia 15 kwietnia 2011 r. o działalności leczniczej [Act of 15 April 2011 on medical activity], Journal of Laws of 2016, item 1638.

Ustawa z dnia 28 maja 2013 r. o zmianie ustawy - Kodeks pracy oraz niektórych innych ustaw [Act of 28 May 2013 amending the Labour Code Act and certain other laws], Journal of Laws of 2013 , item 675.

Ustawa z dnia 24 lipca 2015 r. o zmianie ustawy - Kodeks pracy oraz niektórych innych ustaw [Act of 24 July 2015 amending the Labour Code Act and certain other laws], Journal of Laws of 2015 , item 1220 .

Rozporządzenie z dnia 12 stycznia 2011 r. w sprawie określenia stanowisk w Służbie Więziennej, na których służbę mogą pełnić wyłącznie funkcjonariusze [Regulation of 12 January 2011 on defining positions in the Prison Service to be filled only by officers], Journal of Laws No. 20, item 106 .

Rozporządzenie z dnia 8 grudnia 2015 r. w sprawie wniosków dotyczących uprawnień pracowników związanych z rodzicielstwem oraz dokumentów dołączanych do takich wniosków [Regulation of 8 December 2015 on applications concerning the parental rights of employees and the documents accompanying such applications], Journal of Laws of 2015, item 2243.

\section{CASE LAW}

Judgement of the Administrative Court of 28 October 2008, file ref. no. I OSK 1721/07, LEX no. 499777.

Judgement of the Court of Appeal in Rzeszów of 6 March 2013, file ref. no. III AUa 1235/12, LEX no. 1292818.

Judgement of the Court of Appeal in Gdańsk of 19 March 2013, file ref. no. III AUa 1577/12, LEX no. 1298892.

Judgement of the Regional Court of Warszawa-Praga in Warsaw of 23 March January 2017, file ref. no. VII U 598/16, LEX no. 2206792.

\section{LITERATURE}

BURY, Beata. "Prawo ojca dziecka niebędącego pracownikiem do realizacji uprawnień rodzicielskich związanych z urlopem macierzyńskim.” Monitor Prawa Pracy 5 (2016): 244-49. 
Ceglarska-JóźWiak, Joanna. "Niezdolność do samodzielnej egzystencji." Praca i Zabezpieczenie Społeczne 2 (2011): 2-20.

HyPś, Sławomir. "Komentarz do art. 210." In Kodeks karny. Komentarz, edited by Alicja Grześkowiak and Krzysztof Wiak, 832-36. Warszawa: Wydawnictwo C.H. Beck, 2014.

Kilińska-PęKACZ, Agnieszka. "Przestępstwo porzucenia dziecka." Prokuratura i Prawo 4 (2016): 22-34.

Ковак, Maciej. “Służba Więzienna.” In Stosunek stużbowy w formacjach mundurowych, edited by Wojciech Maciejko and Przemysław Szustakiewicz. Legalis 2016/el.

KuLIG, Karol. "Członek najbliższej rodziny jako osoba nabywająca uprawnienia związane z rodzicielstwem.” Monitor Prawa Pracy 3 (2016): 135-39.

KumOR-JeZIERSKA, Ewelina. "Komentarz do rozporządzenia z dnia 8 grudnia 2015 r. w sprawie wniosków dotyczących uprawnień pracowników związanych z rodzicielstwem oraz dokumentów dołączanych do takich wniosków." In Akty wykonawcze prawa pracy. Komentarz, edited by Krzysztof Wojciech Baran, 203-83. Warszawa: Wolters Kluwer Polska, 2016.

KumOR-JeZIERSKA, Ewelina. "Dokumentacja w stosunkach zatrudnienia nawiązanych na podstawie ustawy o służbie więziennej." In Dokumenty $w$ zatrudnieniu na podstawie pragmatyk stużbowych. Wzory i komentarze, edited by Krzysztof Wojciech Baran, 533-772. Warszawa: Wolters Kluwer Polska, 2015.

MANIEWSKA, Eliza, and Kazimierz JAŚKOwSKI. Komentarz aktualizowany do Kodeksu pracy. LEX 2017/el.

SEKULSKI, Piotr. "Dopuszczalność zatrudnienia w okresie wykorzystania urlopów związanych z rodzicielstwem." Uprawnienia pracowników zwiąane z rodzicielstwem w świetle przepisów prawa pracy $i$ ubezpieczeń spotecznych, edited by Justyna Czerniak-Swędzioł, 134-56. Warszawa: Wolters Kluwer Polska, 2016.

SовсZук, Arkadiusz. "Prawo dziecka do opieki rodziców jako uzasadnienie dla urlopu i zasiłku macierzyńskiego.” Praca i Zabezpieczenie Społeczne 9 (2015): 11-16.

SoвCZYк, Arkadiusz. Kodeks pracy. Komentarz. Legalis 2017/el.

Stefański, Ryszard A. "Przestępstwo porzucenia." Prokuratura i Prawo 5 (1997): 47-48.

RAtAJCZAK, Aleksander. "Przestępstwa przeciwko rodzinie, opiece i młodzieży w systemie polskiego prawa karnego (zagadnienia wybrane)." Warszawa: Wydawnictwo Prawnicze, 1980.

WŁodARCZYK, Mirosław. Kodeks pracy. Komentarz, edited by Krzysztof Wojciech Baran, 533772. Warszawa: Wolters Kluwer Polska, LEX 2016 el.

ZIELENIECKI, Maciej. Prawo pracy, edited by Jakub Stelina. Warszawa: Wydawnictwo C.H. Beck, 2016.

\section{MATERNITY LEAVE \\ OF A PRISON SERVICE OFFICER}

Summary

The study examines maternity leave regulations in a situation where both parents or legal guardians of a child are officers of the Polish Prison Service, or one of them is a PS officer, and the other is an employee or insured on the basis other than the employment relationship, e.g. a contract of mandate. The latest amendment of 24 July 2015 amending the Labour Code Act and 
certain other laws has extended the range of cases where it is possible for other eligible persons to use part of maternity leave. The new solution enable not only the parents of the child but also other immediate family members to use part of maternity leave. The complexity of the provisions related to parental rights makes interpretation difficult. Moreover, neither the Prison Service Act nor the provision of Article 29 para. 5 of the Act on cash benefits from social insurance, referred to by the Labour Code, specifies which specific persons can be regarded as the closest family. Proper determination of entitled persons is crucial, as it entails the payment of benefits financed by the State, and also, on the basis of the Act on Prison Service, the legislator guarantees protection of the public service relationship by virtue of Article 108 to officers (regardless of the eligible person's gender and the degree of relationship) taking maternity leave or holiday leave on the terms of maternity leave.

Key words: parental rights; immediate family member; father raising a child; protection of public service relationship; child care.

\section{Translated by Tomasz Patkowski}

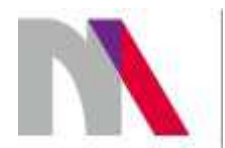

The preparation of the English version of Roczniki Nauk Prawnych (Annals of Iuridical Sciences) and its publication in electronic databases was financed under contract no. 836/PDUN/2018 from the resources of the Minister of Science and Higher Education for the popularization of science. 